\title{
COMBINED EFFECTS OF ORGANIC MANURES AND CHEMICAL FERTILIZERS ON GROWTH AND YIELD OF RED CAPSICUM (CAPSICUM ANNUUM L.) GROWN AT ROOFTOP
}

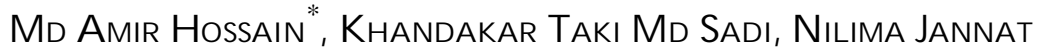 \\ AND MK RAHMAN \\ Department of Soil, Water and Environment, University of Dhaka, \\ Dhaka-1000, Bangladesh
}

Key words: Growth and yield, Organic manure and chemical fertilizer, Red capsicum, Trichocompost

\begin{abstract}
A pot experiment was conducted to evaluate the effects of organic manures and inorganic fertilizers on the growth and yield of red capsicum (Capsicum annuum L.). It was conducted on rooftop of a building in Bogura town, Bogura. The experiment consisted of twelve treatments with three replications and was laid out in Randomized Complete Block Design (RCBD). Treatments were $\mathrm{T}_{1}$ : Control (-OM and -NPK), T2: 4 ton Nafco ha ${ }^{-1}+\mathrm{N}_{23} \mathrm{P}_{10} \mathrm{~K}_{25} \mathrm{kgha}^{-1}, \mathrm{~T}_{3}: 4$ ton ACI ha-1 $+\mathrm{N}_{23} \mathrm{P}_{10} \mathrm{~K}_{25}$ kgha- $^{-1}, \mathrm{~T}_{4}: 4$ ton Trichocompost ha ${ }^{-1}+\mathrm{N}_{23} \mathrm{P}_{10} \mathrm{~K}_{25}$ kgha $^{-1}$, T5: 4 ton Kazi Farms ha- ${ }^{-1}+\mathrm{N}_{23} \mathrm{P}_{10} \mathrm{~K}_{25}$ kgha-1 $^{-1}, \mathrm{~T}_{6}: 4$ ton Mimpex ha- ${ }^{-1}+\mathrm{N}_{23} \mathrm{P}_{10} \mathrm{~K}_{25} \mathrm{kgha}^{-1}$, $\mathrm{T}_{7}: 4$ ton Mazim ha ${ }^{-1}+\mathrm{N}_{23} \mathrm{P}_{10} \mathrm{~K}_{25}$ kgha $^{-1}, \mathrm{~T}_{8}: 4$ ton McDonald ha-1 $+\mathrm{N}_{23} \mathrm{P}_{10} \mathrm{~K}_{25} \mathrm{kgha}^{-1}, \mathrm{~T}_{9}: 4$ ton Paragon ha ${ }^{-1}+\mathrm{N}_{23} \mathrm{P}_{10} \mathrm{~K}_{25}$ kgha $^{-1}, \mathrm{~T}_{10}: 4$ ton Kazi Agro ha ${ }^{-1}+\mathrm{N}_{23} \mathrm{P}_{10} \mathrm{~K}_{25}$ kgha-1 $^{-1} \mathrm{~T}_{11}: 4$ ton Vermicompost ha ${ }^{-1}+\mathrm{N}_{23} \mathrm{P}_{10} \mathrm{~K}_{25} \mathrm{kgha}^{-1}$ and $\mathrm{T}_{12}: \mathrm{N}_{46} \mathrm{P}_{20} \mathrm{~K}_{50} \mathrm{kgha}^{-1}$. Highest plant height $(33.81 \mathrm{~cm})$, leaf area $\left(87.22 \mathrm{~cm}^{2}\right.$ plant $\left.{ }^{-1}\right)$, number of leaves (43 plant $\left.{ }^{-1}\right)$, number of branches $\left(6\right.$ plant $\left.^{-1}\right)$, number of fruits $\left(11\right.$ plant $\left.^{-1}\right)$, fresh weight $\left(0.60 \mathrm{~g}^{-1}\right.$ plant $\left.^{-1}\right)$ and dry weight $\left(12.67\right.$ g plant $\left.^{-1}\right)$ were observed in treatment $\mathrm{T}_{4}: 4$ ton Trichocompost ha-1 $+\mathrm{N}_{23} \mathrm{P}_{10} \mathrm{~K}_{25} \mathrm{kgha}^{-1}$. Highest girth $(3.18 \mathrm{~cm})$ was observed in treatment $\mathrm{T}_{7}$ : 4 ton Mazim ha ${ }^{-1}+\mathrm{N}_{23} \mathrm{P}_{10} \mathrm{~K}_{25} \mathrm{kgha}^{-1}$. The overall best growth performance was achieved in $\mathrm{T}_{4}: 4$ ton Trichocompost ha- ${ }^{-1}+\mathrm{N}_{23} \mathrm{P}_{10} \mathrm{~K}_{25}$ kgha-1 $^{-1}$ treatment.
\end{abstract}

\section{Introduction}

Red capsicum (Capsicum annuum L.) belongs to the family Solanaceae and commonly known as bell pepper. Sweet pepper includes different cultivars and the most commonly used ones are hybrids that have bell-shaped. Bell peppers are of different colors ranging from green to yellow, red, orange, purple, and black. Chilli is an important commercial spice vegetable and medicine used all over the world due to its pungency odour, taste, flavor and high colouring substance. Fruits are rich source of vitamin C, A and E and anti- oxidant ${ }^{(1,2)}$. During the past few decades, intensive farming has been practiced to increase crop yield per unit area. Excessive amounts of inorganic fertilizers are generally

*Author for correspondence: mdamir-2015817376@swe.du.ac.bd 
applied to vegetable crops to obtain higher yield(3). The present soil fertility status of Bangladesh is alarming due to excess use of inorganic fertilizers ${ }^{(4)}$. Continuous cultivation of soil using inorganic fertilizers has been implicated in reduction of soil organic carbon and organic matter, nutrient imbalance, deficiency of secondary macronutrients and micronutrients ${ }^{(5)}$. There is no doubt that chemical fertilizers are playing a vital role to meet the nutrient requirement of crops and thereby increase their production. On the other hand, the use of organic manures is beneficial to the soil in terms of alleviating soil acidity, enhancement of soil physical properties and nutrient status( ${ }^{(6)}$. Organic manures not only improve the soil physical, chemical and biological properties but also improve the moisture holding capacity of soil. Organic manure can enhance crop productivity with better quality yield ${ }^{(4)}$. Since the nutrient turnover in soil plant system is considerably high in intensive farming, neither the chemical fertilizers nor the organic and biological sources alone can achieve production sustainability ${ }^{(7)}$. Sole application of organic sources cannot maintain and synchronize the required nutrient supply to the growing plant due to lesser quantity of mineral nutrients or time needed for their mineralization to release nutrients for plant uptake ${ }^{(8)}$. Likewise, chemical fertilizers, even with balanced use, could not maintain high yield level over the years because of deterioration in soil physical and biological environments due to low organic matter content in soils ${ }^{(9)}$. Organically grown crops are believed to provide healthier and nutritionally superior food for men and animals than those grown with commercial manures ${ }^{(10)}$.

In recent times, the concept of integrated nutrient management has been receiving increasing attention worldwide obviously for reasons of economization of fertilizer usage, safeguarding and ensuring scientific management of soil health for optimum growth, yield and quality of crops in an integrated manner in a specific agro-ecological situations, through balanced use of organic and inorganic plant nutrients; so that one can harvest good yield without deteriorating soil health. Maintaining soil fertility status has been seen as one of the best soil management practices that influence sweet pepper productivity. The best option to maintain soil fertility as well as higher yield is through application of organic and inorganic fertilizers ${ }^{(11)}$.

Use of inorganic fertilizers and organic manures has assumed a great significance in recent years in vegetables production for two reasons. Firstly, the need for continued increase production and per hectare yield of vegetables requires the increase amount of nutrients. Secondly, the results of a large number of experiments on inorganic and organic fertilizers conducted in several countries reveal that inorganic fertilizer alone cannot sustain the productivity of soils under highly intensive cropping systems ${ }^{(12)}$. Therefore, to keep the environment clean and to fulfill the demand of red capsicum for the people of town the present experiment was carried out to study the effects of organic manures and inorganic fertilizers on the growth and yield of red capsicum grown at rooftop in pots. 


\section{Materials and Methods}

Soil sample collection and analysis: Soil sample was collected from Gabtali, Bogura, Bangladesh which is situated at $24^{\circ} 53^{\prime} 24^{\prime \prime} \mathrm{N}$ latitude and $89^{\circ} 27^{\prime \prime} 5^{\prime \prime} \mathrm{E}$ longitude. The sample was collected from $0-15 \mathrm{~cm}$ depth. The sample was air- dried, grounded by using wooden hammer and sieved through $2 \mathrm{~mm}$ sieve. The soil was silty clay in texture $^{(13)}$ with $\mathrm{pH}$ 5.4. Organic carbon ${ }^{(14)}$, total nitrogen $(\mathrm{N})^{(15)}$, available phosphorus $(\mathrm{P})^{(16)}$ and exchangeable potassium $(\mathrm{K})^{(17)}$ was found $1.56 \%, 0.102 \%, 5.3 \mu \mathrm{g} \mathrm{g}^{-1}$ and 0.195 $\mu \mathrm{g} \mathrm{g}^{-1}$, respectively.

Pot experiment: A pot experiment was conducted at Bogura Sadar, Bogura, Bangladesh. Ten types of different organic manures and three types of inorganic fertilizers were collected from local market. The experiment was consisted of twelve treatments with three replications and laid out in Randomized Completely Block Design (RCBD). Six kilogram soil per plastic pot (height $23 \mathrm{~cm}$ and diameter $25.5 \mathrm{~cm}$ ) was used. Organic manures at the rate of 4 ton ha, N 23 and $46 \mathrm{kgha}^{-1}$ as urea, P 10 and $20 \mathrm{kgha}^{-1}$ as di-ammonium phosphate (DAP) and $\mathrm{K} 25$ and $50 \mathrm{kgha}^{-1}$ as muriate of potash (MoP) were applied. Treatments were: $\mathrm{T}_{1}$ : Control (-OM and -NPK), $\mathrm{T}_{2}: 4$ ton Nafco ha-1 + $\mathrm{N}_{23} \mathrm{P}_{10} \mathrm{~K}_{25}$ kgha $^{-1}, \mathrm{~T}_{3}: 4$ ton ACI ha ${ }^{-1}+\mathrm{N}_{23} \mathrm{P}_{10} \mathrm{~K}_{25}$ kgha $^{-1}, \mathrm{~T}_{4}: 4$ ton Trichocompost ha- ${ }^{-1}+$ $\mathrm{N}_{23} \mathrm{P}_{10} \mathrm{~K}_{25}$ kgha- $^{-1}$, $\mathrm{T}_{5}: 4$ ton Kazi Farms ha-1 $+\mathrm{N}_{23} \mathrm{P}_{10} \mathrm{~K}_{25}$, $\mathrm{T}_{6}: 4$ ton Mimpex ha-1 $+\mathrm{N}_{23} \mathrm{P}_{10} \mathrm{~K}_{25}$ kgha- $^{-1}$, T7: 4 ton Mazim ha-1 $+\mathrm{N}_{23} \mathrm{P}_{10} \mathrm{~K}_{25}$ kgha $^{-1}$, T8: 4 ton McDonald ha-1 $+\mathrm{N}_{23} \mathrm{P}_{10} \mathrm{~K}_{25}$ kgha- $^{-1}$, T: 4 ton Paragon ha- ${ }^{-1}+\mathrm{N}_{23} \mathrm{P}_{10} \mathrm{~K}_{25}$ kgha- $^{-1}, \mathrm{~T}_{10}: 4$ ton Kazi Agro ha- ${ }^{-1}+\mathrm{N}_{23} \mathrm{P}_{10} \mathrm{~K}_{25}$ kgha $^{-1}, \mathrm{~T}_{11}: 4$ ton Vermicompost ha ${ }^{-1}+\mathrm{N}_{23} \mathrm{P}_{10} \mathrm{~K}_{25} \mathrm{kgha}^{-1}$ and $\mathrm{T}_{12}$ : $\mathrm{N}_{46} \mathrm{P}_{20} \mathrm{~K}_{50} \mathrm{kgha}^{-1}$. Four weeks old seedlings of red capsicum were collected from Horticulture Center, Bogura, Bangladesh and one seedling was transplanted per pot. Growth parameters were measured at 15 days interval up to 120 days. Watering, spraying and necessary intercultural operations were done accordingly.

Harvesting: Plants were harvested as root, stem, leaves and fruits, and fresh weight were recorded. Roots were washed with tap water and finally with distilled water, and wrapped with soft tissue paper. Then samples were air-dried in the room temperature and finally oven-dried at $65^{\circ} \mathrm{C}$ in the laboratory for two days. The dry weight of the samples was measured and the samples were grounded with a mechanical grinder and stored in the polythene bags. The obtained data for different parameters were evaluated by the Least Significant Difference (LSD) test at 5\% level of probability using IBM SPSS Statistics 25 .

\section{Results and Discussion}

Plant height: Results in Table 1 showed that plant height of red capsicum affected by the application of combined organic and inorganic fertilizer. Plant height of red capsicum varied significantly ( $\mathrm{p} \leq 0.05$ ) at 45, 60,75, 90 and 120 days for different combinations of organic and inorganic fertilizers (Table 1). The highest $(33.81 \mathrm{~cm})$ plant height was 
recorded from $\mathrm{T}_{4}$ (4 ton Trichocompost ha- $\left.{ }^{-1}+\mathrm{N}_{23} \mathrm{P}_{10} \mathrm{~K}_{25}\right)$ compared to control $\mathrm{T}_{1}(22.13 \mathrm{~cm}$ ) and inorganic fertilizer $T_{12}(23.21 \mathrm{~cm}) 120$ day at harvest. Highest plant height was observed at treatment $\mathrm{T}_{4}$ followed by $\mathrm{T}_{6}, \mathrm{~T}_{11}, \mathrm{~T}_{2}, \mathrm{~T}_{10}, \mathrm{~T}_{3}, \mathrm{~T}_{7}, \mathrm{~T}_{9}, \mathrm{~T}_{8}, \mathrm{~T}_{12}, \mathrm{~T}_{5}$ and $\mathrm{T}_{1}$. This might

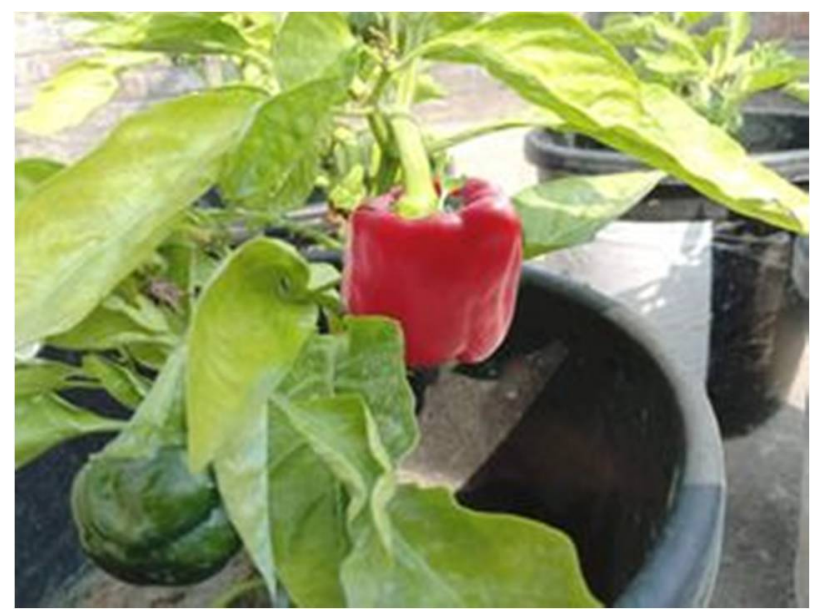

Fig. 1. A red capsicum plant grown in 4 ton Trichocompost ha ${ }^{-1}+\mathrm{N}_{23} \mathrm{P}_{10} \mathrm{~K}_{25} \mathrm{~kg} \mathrm{ha}^{-1}$.

Table 1. Effects of different organic manures and inorganic fertilizers on the height $(\mathrm{cm})$ of red capsicum plant.

\begin{tabular}{ccccccccc}
\hline & \multicolumn{7}{c}{ Days after transplanting } \\
\cline { 2 - 9 } $\mathrm{T}_{1}$ & $15 \mathrm{~d}$ & $30 \mathrm{~d}$ & $45 \mathrm{~d}$ & $60 \mathrm{~d}$ & $75 \mathrm{~d}$ & $90 \mathrm{~d}$ & $105 \mathrm{~d}$ & $120 \mathrm{~d}$ \\
\cline { 2 - 9 } $\mathrm{T}_{2}$ & 11.83 & 17.43 & 20.73 & 21.50 & 21.90 & 21.93 & 22.10 & 22.13 \\
$\mathrm{~T}_{3}$ & 12.00 & 19.53 & 24.57 & 25.17 & 25.67 & 25.73 & 25.57 & 25.58 \\
$\mathrm{~T}_{4}$ & 13.87 & 21.03 & 27.67 & 30.17 & 32.20 & 33.37 & 33.80 & 33.81 \\
$\mathrm{~T}_{5}$ & 10.50 & 19.83 & 21.57 & 21.97 & 22.33 & 22.57 & 22.90 & 22.94 \\
$\mathrm{~T}_{6}$ & 13.00 & 21.70 & 27.77 & 29.90 & 30.23 & 30.37 & 30.40 & 30.42 \\
$\mathrm{~T}_{7}$ & 10.93 & 21.40 & 24.13 & 24.40 & 24.57 & 24.80 & 24.70 & 24.72 \\
$\mathrm{~T}_{8}$ & 10.23 & 14.53 & 17.40 & 20.83 & 22.73 & 23.10 & 23.63 & 23.64 \\
$\mathrm{~T}_{9}$ & 11.47 & 16.70 & 22.73 & 23.77 & 24.07 & 24.13 & 24.17 & 24.19 \\
$\mathrm{~T}_{10}$ & 12.33 & 19.60 & 22.93 & 23.53 & 24.20 & 24.33 & 25.40 & 25.41 \\
$\mathrm{~T}_{11}$ & 10.27 & 19.67 & 24.70 & 24.83 & 25.17 & 25.23 & 25.93 & 25.95 \\
$\mathrm{~T}_{12}$ & 11.97 & 16.73 & 21.13 & 21.87 & 22.37 & 22.63 & 23.20 & 23.21 \\
LSD at 5\% & $\mathrm{NS}$ & $\mathrm{NS}$ & 16.46 & 12.31 & 13.55 & 11.78 & 10.76 & 10.77 \\
\hline
\end{tabular}


be due to continuous supply of nutrients possibly from organic source which helped for better growth of the plants. Several studies have indicated that plant height increased by the application of chemical fertilizers and organic manures ${ }^{(14,18)}$. Chilli crop responds well to the application of both organic and inorganic fertilizers. Recommended dose of chemical fertilizer $\left(\mathrm{N}_{100} \mathrm{P}_{60} \mathrm{~K}_{100} \mathrm{~S}_{20} \mathrm{Zn}_{2} \mathrm{~B}_{1} \quad \mathrm{kgha}^{-1}\right)$ in combination with 5 ton ha- ${ }^{-1}$ cowdung produced highest yield of dry chilli at Bogura (1.74 tonha-1) and Hathazari (1.36

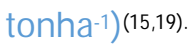

Number of leaves: The number of leaves per plant at different stages of growth showed significant variation among the different treatments (Table 2). The highest number (43 per plant) of leaves was recorded in $\mathrm{T}_{4}$ (4 ton Trichocompost ha- $\left.{ }^{-1}+\mathrm{N}_{23} \mathrm{P}_{10} \mathrm{~K}_{25} \mathrm{kgha}^{-1}\right)$ compared to control $\mathrm{T}_{1}$ (26 per plant) and inorganic fertilizer $\mathrm{T}_{12}$ (30 per plant). Zaman and Talukder ${ }^{(16)} 20$ carried out an experiment on chilli at Jamalpur district and found the highest dry yield of chilli (2.15 tonha- $\left.{ }^{-1}\right)$ at $\mathrm{N}_{120} \mathrm{P}_{60} \mathrm{~K}_{120} \mathrm{~S}_{18} \mathrm{Zn}_{2} \mathrm{~B}_{0.5} \mathrm{kgha}^{-1}$ with 5 ton ha- ${ }^{-1}$ of cow dung.

Table 2. Effects of different organic manures and inorganic fertilizers on the number of leaf of red capsicum plant.

\begin{tabular}{lcccccccc}
\hline \multirow{2}{*}{ Treatments } & \multicolumn{7}{c}{ Days after transplanting } \\
\cline { 2 - 8 } & $15 \mathrm{~d}$ & $30 \mathrm{~d}$ & $45 \mathrm{~d}$ & $60 \mathrm{~d}$ & $75 \mathrm{~d}$ & $90 \mathrm{~d}$ & $105 \mathrm{~d}$ & $120 \mathrm{~d}$ \\
\hline $\mathrm{T}_{1}$ & 9 & 12 & 15 & 17 & 20 & 21 & 24 & 26 \\
$\mathrm{~T}_{2}$ & 9 & 17 & 28 & 28 & 31 & 33 & 35 & 37 \\
$\mathrm{~T}_{3}$ & 7 & 12 & 15 & 18 & 22 & 24 & 26 & 28 \\
$\mathrm{~T}_{4}$ & 8 & 15 & 27 & 32 & 35 & 37 & 41 & 43 \\
$\mathrm{~T}_{5}$ & 8 & 20 & 22 & 24 & 26 & 30 & 31 & 33 \\
$\mathrm{~T}_{6}$ & 8 & 17 & 21 & 24 & 26 & 29 & 31 & 33 \\
$\mathrm{~T}_{7}$ & 8 & 23 & 17 & 20 & 23 & 26 & 29 & 31 \\
$\mathrm{~T}_{8}$ & 8 & 12 & 16 & 19 & 21 & 24 & 28 & 30 \\
$\mathrm{~T}_{9}$ & 8 & 14 & 20 & 20 & 23 & 25 & 28 & 31 \\
$\mathrm{~T}_{10}$ & 7 & 22 & 24 & 26 & 29 & 31 & 33 & 35 \\
$\mathrm{~T}_{11}$ & 7 & 11 & 14 & 18 & 22 & 22 & 28 & 32 \\
$\mathrm{~T}_{12}$ & 7 & 11 & 14 & 17 & 21 & 21 & 27 & 30 \\
$\mathrm{LSD}$ at $5 \%$ & $\mathrm{NS}$ & $\mathrm{NS}$ & 16.1 & 13.81 & 10.63 & 9.55 & 6.93 & 3.6 \\
\hline
\end{tabular}

Number of branches: Highest number of branches ( 6 per plant) and the lowest number of branches ( 3 per plant) was recorded at $\mathrm{T}_{4}$ ( 4 ton Trichocompost ha-1 $+\mathrm{N}_{23} \mathrm{P}_{10} \mathrm{~K}_{25}$ kgha-1 $\left.^{-1}\right)$ and $T_{1}$ (control) respectively (Table 3 ). Other treatments showed intermediate effects. Zaman et al.(17,21) reported that the different sources of nitrogenous fertilizers had significant influence on the plant height, number of branches per plant, fruit size and fruit yield per plant of chilli. 
Table 3. Effects of different organic manures and inorganic fertilizers on the number of branch of red capsicum plant.

\begin{tabular}{ccccccc}
\hline \multirow{2}{*}{ Treatments } & \multicolumn{7}{c}{ Days after transplanting } \\
\cline { 2 - 7 } & $45 \mathrm{~d}$ & $60 \mathrm{~d}$ & $75 \mathrm{~d}$ & $90 \mathrm{~d}$ & $105 \mathrm{~d}$ & $120 \mathrm{~d}$ \\
\hline $\mathrm{T}_{1}$ & 0 & 1 & 1 & 2 & 3 & 3 \\
$\mathrm{~T}_{2}$ & 2 & 4 & 4 & 4 & 5 & 5 \\
$\mathrm{~T}_{3}$ & 1 & 2 & 3 & 3 & 4 & 4 \\
$\mathrm{~T}_{4}$ & 2 & 3 & 3 & 4 & 4 & 5 \\
$\mathrm{~T}_{5}$ & 2 & 3 & 4 & 4 & 5 & 5 \\
$\mathrm{~T}_{6}$ & 1 & 3 & 3 & 3 & 4 & 4 \\
$\mathrm{~T}_{7}$ & 4 & 5 & 5 & 6 & 6 & 6 \\
$\mathrm{~T}_{8}$ & 1 & 2 & 3 & 3 & 3 & 3 \\
$\mathrm{~T}_{9}$ & 2 & 3 & 3 & 4 & 4 & 4 \\
$\mathrm{~T}_{10}$ & 4 & 4 & 5 & 5 & 5 & 5 \\
$\mathrm{~T}_{11}$ & 2 & 4 & 4 & 4 & 5 & 5 \\
$\mathrm{~T}_{12}$ & 2 & 3 & 4 & 4 & 5 & 5 \\
LSD at $5 \%$ & $\mathrm{NS}$ & 1.31 & 1.31 & 0.7 & 0.89 & 0.84 \\
\hline
\end{tabular}

Table 4. Effects of different organic manures and inorganic fertilizers on the girth $(\mathrm{cm})$ of red capsicum plant.

\begin{tabular}{cccccccc}
\hline \multirow{2}{*}{ Treatments } & \multicolumn{7}{c}{ Days after transplanting } \\
\cline { 2 - 8 } & $30 \mathrm{~d}$ & $45 \mathrm{~d}$ & $60 \mathrm{~d}$ & $75 \mathrm{~d}$ & $90 \mathrm{~d}$ & $105 \mathrm{~d}$ & $120 \mathrm{~d}$ \\
\hline $\mathrm{T}_{1}$ & 1.43 & 1.77 & 1.83 & 1.83 & 1.97 & 2.03 & 2.05 \\
$\mathrm{~T}_{2}$ & 2.15 & 2.40 & 2.43 & 2.57 & 2.67 & 2.73 & 2.74 \\
$\mathrm{~T}_{3}$ & 2.07 & 2.33 & 2.37 & 2.43 & 2.60 & 2.67 & 2.68 \\
$\mathrm{~T}_{4}$ & 2.23 & 2.47 & 2.57 & 2.63 & 2.80 & 2.97 & 2.99 \\
$\mathrm{~T}_{5}$ & 2.37 & 2.60 & 2.67 & 2.73 & 2.73 & 2.83 & 2.84 \\
$\mathrm{~T}_{6}$ & 2.10 & 2.37 & 2.57 & 2.60 & 2.67 & 2.73 & 2.75 \\
$\mathrm{~T}_{7}$ & 2.73 & 2.80 & 2.93 & 3.00 & 3.13 & 3.17 & 3.18 \\
$\mathrm{~T}_{8}$ & 2.10 & 2.17 & 2.23 & 2.37 & 2.40 & 2.50 & 2.52 \\
$\mathrm{~T}_{9}$ & 2.30 & 2.73 & 2.77 & 2.80 & 2.87 & 2.93 & 2.94 \\
$\mathrm{~T}_{10}$ & 2.40 & 2.47 & 2.50 & 2.57 & 2.67 & 2.73 & 2.74 \\
$\mathrm{~T}_{11}$ & 2.27 & 2.37 & 2.60 & 2.70 & 2.83 & 2.87 & 2.89 \\
$\mathrm{~T}_{12}$ & 1.83 & 2.37 & 2.40 & 2.43 & 2.53 & 2.60 & 2.61 \\
LSD at $5 \%$ & 0.21 & 0.15 & 0.09 & 0.07 & 0.05 & 0.05 & 0.04 \\
\hline
\end{tabular}


Girth: A significant variation was found in girth per plant due to different organic and inorganic fertilizers application at different stages of growth (Table 4). The highest girth $(3.18 \mathrm{~cm})$ of the plant was observed in $\mathrm{T}_{7}\left(4\right.$ ton Mazim ha- $\left.{ }^{-1}+\mathrm{N}_{23} \mathrm{P}_{10} \mathrm{~K}_{25} \mathrm{kgha}^{-1}\right)$ which was followed by $T_{4}, T_{9}, T_{11}, T_{5}, T_{6}, T_{10}, T_{2}, T_{3}, T_{12}, T_{8}$ and $T_{1}$ treatments at harvest. Petter et al.(18,22) confirmed that integrated application of organic and inorganic fertilizers significantly increased plant growth and crop productivity.

Fruits: The highest number of fruits (11 per plant) was recorded in $\mathrm{T}_{4}$ (4 ton Trichocompost ha-1 $+\mathrm{N}_{23} \mathrm{P}_{10} \mathrm{~K}_{25} \mathrm{kgha}^{-1}$ ) compared to control $\mathrm{T}_{1}$ (4 per plant) (Table 5). Highest fruit length and diameter was observed in $\mathrm{T}_{4}(4$ ton Trichocompost ha-1 + $\mathrm{N}_{23} \mathrm{P}_{10} \mathrm{~K}_{25} \mathrm{kgha}^{-1}$ ) was $10.5 \mathrm{~cm}$ and $6.5 \mathrm{~cm}$, respectively. Nawrin et al.(19,23) reported that the overall best growth, yield and nutrient accumulation in the fruits of chilli were achieved in $\mathrm{B}_{0.5} \mathrm{kgha}^{-1}+\mathrm{VC}_{5}$ tonha ${ }^{-1}$ treatment.

Table 5. Effects of different organic manures and inorganic fertilizers on the fruits of red capsicum plant.

\begin{tabular}{lcccccc}
\hline \multirow{2}{*}{ Treatments } & \multicolumn{3}{c}{ Days after transplanting } & \multicolumn{2}{c}{ Weight (g) } \\
\cline { 2 - 4 } & $\begin{array}{c}\text { Number } \\
\text { of fruits }\end{array}$ & $\begin{array}{c}\text { Highest length } \\
\text { of fruits }(\mathrm{cm})\end{array}$ & $\begin{array}{c}\text { Highest diameter } \\
\text { of fruits (cm) }\end{array}$ & & Fresh & Dry \\
\hline $\mathrm{T}_{1}$ & 4 & 4.5 & 2.8 & 15.00 & 2.00 \\
$\mathrm{~T}_{2}$ & 8 & 5.2 & 3.2 & 20.00 & 2.33 \\
$\mathrm{~T}_{3}$ & 7 & 5.8 & 4.2 & 30.67 & 2.00 \\
$\mathrm{~T}_{4}$ & 11 & 10.5 & 6.5 & 56.00 & 0.70 \\
$\mathrm{~T}_{5}$ & 7 & 6.0 & 4.3 & 36.33 & 4.33 \\
$\mathrm{~T}_{6}$ & 8 & 6.2 & 3.4 & 34.33 & 3.60 \\
$\mathrm{~T}_{7}$ & 10 & 7.8 & 4.0 & 43.00 & 2.77 \\
$\mathrm{~T}_{8}$ & 6 & 5.0 & 3.0 & 26.00 & 2.00 \\
$\mathrm{~T}_{9}$ & 6 & 10 & 6.0 & 55.00 & 3.00 \\
$\mathrm{~T}_{10}$ & 8 & 5.6 & 4.2 & 33.67 & 3.63 \\
$\mathrm{~T}_{11}$ & 9 & 6.5 & 4.4 & 37.00 & 3.93 \\
$\mathrm{~T}_{12}$ & 6 & 6.8 & 4.4 & 34.00 & 3.00 \\
$\mathrm{LSD}_{5}$ at $5 \%$ & - & - & - & 34.64 & 0.31 \\
\hline
\end{tabular}

Fresh and dry weight of plants: Fresh weight of roots and leaves per plant did not differ significantly $(\mathrm{p}<0.05)$. The highest shoot weight $\left(12.67 \mathrm{~g} \mathrm{plant}^{-1}\right)$ and the lowest $(4 \mathrm{~g}$ plant $^{-1}$ ) was observed in treatment $T_{4}$ and $T_{1}$, respectively. Dry weight of shoot and root did not vary significantly $(\mathrm{p}<0.05)$. The highest dry weight of root $\left(0.60 \mathrm{~g} \mathrm{plant}^{-1}\right)$ was 
Table 6. Effects of different organic manures and inorganic fertilizers on the fresh and dry weight of red capsicum plant.

\begin{tabular}{lcccccccc}
\hline Treatments & \multicolumn{3}{c}{ Fresh weight $\left(\mathrm{g} \mathrm{plant}^{-1}\right)$} & \multicolumn{3}{c}{ Dry weight $\left(\mathrm{g} \mathrm{plant}^{-1}\right)$} \\
\cline { 2 - 9 } & Root & Shoot & Leaf & Total & Root & Shoot & Leaf & Total \\
\hline $\mathrm{T}_{1}$ & 1.00 & 4.00 & 2.00 & 7.00 & 0.40 & 1.50 & 0.50 & 2.40 \\
$\mathrm{~T}_{2}$ & 1.00 & 6.00 & 4.33 & 11.33 & 0.40 & 0.63 & 0.63 & 1.67 \\
$\mathrm{~T}_{3}$ & 1.00 & 6.33 & 4.00 & 11.33 & 0.40 & 1.60 & 0.57 & 2.57 \\
$\mathrm{~T}_{4}$ & 1.33 & 12.67 & 5.00 & 19.00 & 0.47 & 1.83 & 0.65 & 2.95 \\
$\mathrm{~T}_{5}$ & 1.00 & 6.67 & 3.67 & 11.33 & 0.40 & 1.60 & 0.53 & 2.53 \\
$\mathrm{~T}_{6}$ & 1.33 & 10.67 & 5.00 & 17.00 & 0.47 & 1.80 & 0.63 & 2.90 \\
$\mathrm{~T}_{7}$ & 1.00 & 5.00 & 4.33 & 10.33 & 0.40 & 1.70 & 0.67 & 2.77 \\
$\mathrm{~T}_{8}$ & 1.33 & 5.33 & 2.33 & 9.00 & 0.47 & 1.53 & 0.50 & 2.50 \\
$\mathrm{~T}_{9}$ & 1.67 & 7.67 & 3.33 & 12.67 & 0.57 & 1.67 & 0.53 & 2.77 \\
$\mathrm{~T}_{10}$ & 1.33 & 6.67 & 2.67 & 10.67 & 0.47 & 1.60 & 0.53 & 2.60 \\
$\mathrm{~T}_{11}$ & 2.00 & 9.00 & 4.00 & 15.00 & 0.60 & 1.73 & 0.60 & 2.93 \\
$\mathrm{~T}_{12}$ & 1.00 & 6.33 & 4.00 & 11.33 & 0.40 & 1.60 & 0.60 & 2.60 \\
$\mathrm{LSD}$ at $5 \%$ & $\mathrm{NS}$ & 6.41 & $\mathrm{NS}$ & - & 0.01 & NS & NS & - \\
\hline
\end{tabular}

observed in 4 ton Vermicompost ha- ${ }^{-1}+\mathrm{N}_{23} \mathrm{P}_{10} \mathrm{~K}_{25}$ kgha $^{-1}$ and lowest in control $(0.40$ g plant 1). Chilli is a rich source of vitamins $\mathrm{A}, \mathrm{C}$ and $\mathrm{E}$ where $100 \mathrm{~g}$ of edible portions contains 24 $\mathrm{kcal}$ of energy, $1.3 \mathrm{~g}$ of protein, $4.3 \mathrm{~g}$ of carbohydrate and $0.3 \mathrm{~g}$ of fat ${ }^{(20,24)}$. Results revealed that the overall growth and yield performance of red capsicum were better in $\mathrm{T}_{4}: 4$ ton Trichocompost ha- ${ }^{-1}+\mathrm{N}_{23} \mathrm{P}_{10} \mathrm{~K}_{25}$ kgha- $^{-1}$ treatment.

\section{Acknowledgements}

Authors would like to thank to Mr. Md. Ashrafuzzaman, Agriculture Extension Officer, Pirgacha, Rangpur for his kind help and support.

\section{References}

1. Marthandan V and K Sundarlingam 2016. Effect of organic sources of nutrients on growth parameters and seed yield in chilli cv. PKM 1. Int. J. Agril. Sci. Res. 6(1): 235-240.

2. Yousuf MN, MM Kamal, MM Akand, MN Akhter and N Nath 2012. Nutrient management for chilli (Capsicum annuum L.). Int. J. Ecotoxicol. Agric. Technol. 2(2): 39-43.

3. Prradhiepan T, TH Seran and G Harihara 2018. Effect of integrated nutrient management on green pod yield of chilli (Capsicum annuum L.) cv MIPC-01. Sabaragamuwa Univ. J. 16(1): 28-33. 
4. BARC (Bangladesh Agricultural Research Council) 2005. Fertilizer Recommendation Guide. Bangladesh Agricultural Research Council, Farmgate, New airport road, Dhaka. pp. 260.

5. Osundare B 2004. Effect of different companion crops and fertilizer types on soil nutrient dynamics and performance of cassava. Nigerian J. Soil Sci. 14: 13-17.

6. Ano OA and JA Agwu 2005. Effect of animal manure on selected soil chemical properties. Nigerian J. Soil Sci. 15: 14-19.

7. Javaria $S$ and MQ Khan 2011. Impact of integrated nutrient management on tomato yield and quality and soil environment. J. Plant Nutrition 34: 140-149.

8. Akhtar M, A Naeem, SA Bokhari and J Akhter 2011. Improvement in nutrient uptake and yield of wheat by combined use of urea and compost. Soil Environ. 30(1): 45-49.

9. Shilpa A, K Sharma, S Thakur and K Sharma 2017. Integrated nutrient management of peppers (Capsicum annuum L.) in 21st Century - A review: Int. J. Curr. Microbiol. App. Sci. 6(12): 227-237.

10. Qulsum U, FF Meem, RS Promi, JR Zaman, MF Ara and MK Rahman 2020. Growth performance of jute (Corchorus capsularies L.) as influenced by different organic manures. J. Biodivers. Conserv. Bioresour. Manag. 6(1): 17-24.

11. Poku Snr PA, CG Kyere, PA Roku Jnr2, E Oppong and G Twumasi 2020. Effects of poultry manure, NPK Fertilizer and their combination on the growth and yield of sweet pepper. Asian J. Agric. Hort. Res. 5(1): 14-22.

12. Singh, GB and DV Yadav 1992. Integrated plant nutrition system in sugarcane. Fertilizer News 37: $15-22$.

13. Bouyoucos GJ 1962. Hydrometer method improved for making particle size analysis of soils. Agron. J. 54: 461-465.

14. Walkley A and IA Black 1934. An examination of the degtjareff method for determining soil organic carbon and a proposed modification for the chromic acid titration method. Soil Sci. 37: 29-38.

15. Marr IL and MS Cresser 1983. The lithosphere. In: Environmental Chemical Analysis. Blackie and Son Ltd. UK. pp. 155-183.

16. Jackson ML 1958. Soil Chemical Analysis. Prentice- Hall, Inc., Englewood Cliffs, NJ, USA. pp. 498.

17. Pratt PF 1965. Potassium. In: Methods of Soil Analysis. Part2. Black CA (ed.). SAA Inc., Madison, Wisconsin. pp. 1022-1030.

18. Hoque AKMS, MMA Patwary, S Brahma, MA Islam and ATM Farid 2004. Integrated nutrient management for chilli. Annual Research Report (2003-2004). Soil Science Division, Bangladesh Agricultural Research Institute (BARI) Gazipur.

19. Hossain S and F Akter 2020. Effects of trichoderma-enriched biofertilizer and farmyard manure on the growth and yield of brinjal (Solanum melongena L.). Dhaka Univ. J. Biol. Sci. 29(1): $1-8$.

20. Zaman MS and MR Talukder 2007. Integrated nutrient management for chilli. Soil Science Division, Bangladesh Agricultural Research Institute, Gazipur.

21. Zaman MS, S Brahma, MN Yousuf, R Ara and MI Haque 2020. Effect of different sources of nitrogen on the growth and yield of chilli. Research Report 2019- 2020. Spices Research Centre, BARI, Shibgonj, Bogura. pp. 35-41. 
22. Petter FA, BE Madar, MAS Silva, MAC Caneiro, MTM Caravalho, BHM Junior and LP Pacheco 2012. Soil fertility and agronomic response of rice to biochar application in the Brazilian savannah. Pesquisa Agropecuarria Brasileira 47(5): 699-706.

23. Nawrin KS, MJ Uddin, AHMZ Ali and MK Rahman 2020. Effects of boron and vermicompost on growth, yield and nutrient content of chilli (Capsicum annum L.). J. Biodivers. Conserv. Bioresour. Manag. 6(1): 31-36.

24. Vijayalakshmi A and V Gayathri 2017. Effect of vermicompost on the growth and yield of chilli. Intl. J. Recent Scientific Res. 8(8): 19540-19542.

(Manuscript received on 15 August, 2021; accepted on 25 November, 2021) 